\title{
Performance Evaluation of Kuroiler and Sasso Chicken Breeds Reared under On-farm and On-station Management Conditions in Tanzania
}

\author{
Fadhili S. Guni, Said H. Mbaga, and Andalwisye M. Katule
}

\section{ABSTRACT}

\begin{abstract}
A study was conducted to evaluate the effect of management, breed, and their interaction on growth performance, egg production, and survivability under on-station and on-farm management conditions in Tanzania. A total of 1200 chicks, 600 for each breed, Kuroiler, and Sasso of mixed sexes were used. Birds under on-station management were confined and fed commercial ration throughout the experiment while those under on-farm management were allowed to semi-scavenge and supplemented with available feeds in the household. Brooding was carried out on-station for six weeks. Thereafter, birds were sub-divided for on-station and on-farm evaluation where data on body weight, egg production traits, and survival rate were taken at different ages from week 6 up to 52. The General Linear Models procedure fitting management, breed, and interaction between management and breed was used to analyze the data. Results show that management conditions had a significant influence on the performance of the breeds. Birds reared onstation performed better in all traits measured than those reared on-farm. The general effect of the breed was significant only for hen-day egg production (HDEP \%) and hen-housed egg production (HHEP) in favour of Sasso chickens. Similarly, Sasso was more efficient at converting feed to live body weight. Interactions between management and breed were observed for all traits except peak egg production rate and mortality rate. While Sasso performance was better than that of Kuroiler on body weight, age at first egg, HDEP, age at peak egg production, and HHEP under the on-station management system, their performance in these traits were similar under the on-farm management except for body weight and age at first egg where Kuroiler was superior to Sasso. The survivability was also higher for Kuroiler than for Sasso under both management systems. It is concluded that genotype by environment (GxE) interaction had significant effects on the performance of the two breeds thus, a need to consider such effect when promoting them for either on-station or on-farm rearing.
\end{abstract}

Keywords: On-station, On-farm, Kuroiler, Sasso, Bodyweight, Egg production, Mortality.

\section{INTRODUCTION}

Poultry production in most developing countries has an important economic, social, and cultural benefit and plays a significant role in family nutrition. About $85 \%$ of the rural populations in sub-Saharan Africa keep chickens which provide a reasonable proportion of animal protein and household cash income [1]. In Tanzania, like many other developing countries, household poultry production is practiced in rural and urban areas for the livelihood of the households i.e., as a source of income and food. Poultry, in particular chicken, production systems in Tanzania have been categorized as unimproved traditional indigenous, improved family, and commercial systems. The traditional system of poultry keeping is predominant, and accounts for $96 \%$ of household flocks and supplies $94 \%$ of poultry meat and eggs in rural areas [2]. However, this system is unable to meet the increasing demand for poultry meat and eggs owing to its low productivity in terms of both egg and meat.
Submitted : February 22, 2021

Published : March 31, 2021

ISSN: $2684-1827$

DOI: $10.24018 /$ ejfood.2021.3.2.254

\section{F. S. Guni*}

Tanzania Livestock Research Institute (TALIRI), Uyole, Mbeya, Tanzania.

(e-mail: fadhili.guni@yahoo.com)

S. H. Mbaga

Department of Animal, Aquaculture and Range Sciences, Sokoine University of Agriculture, Morogoro, Tanzania.

(e-mail: mbagash@yahoo.com)

A. M. Katule

Department of Animal, Aquaculture and Range Sciences, Sokoine University of Agriculture, Morogoro, Tanzania.

(e-mail: andalkat ${ }^{@}$ yahoo.co.uk)

*Corresponding Author
Efforts have been made previously to improve meat and egg production through importations of high producing exotic breeds, particularly in the commercial sector. These efforts are yet to produce the expected output in the tropics, apparently due to a lack of adaptation to the tropical environment. Besides, the selection and breeding of exotic breeds were developed for high-input intensive production systems in temperate regions [3]. The failure of exotic stocks to meet expectations when raised under tropical conditions is often associated with the phenomenon termed 'genotype by environment interaction' [4].

Alternatively, the introduction of tropically adapted dualpurpose chicken breeds suitable for family chicken production has been proposed to be one of the key strategies to improve chicken productivity in the country [5]. Kuroiler and Sasso are among such breeds which have been introduced into the country. Kuroiler originates from India and has been developed through crossing several pure genetic lines of chickens including White Leghorn, Rhode Island Red, Coloured broiler, and local Desi chickens, followed by selection for high 
production performance and ability to thrive in village environment under scavenging or semi-scavenging rearing systems [6]. The second breed is Sasso which originates from France. It has been developed through an intensive selection of traditional colored lines of chickens from France [7]. The two breeds are known for many desirable features of indigenous birds, such as the feather colors for camouflage, ability to escape from predators, resistance to diseases, adaptable to tropical and sub-tropical conditions [8], [9]. They have also the ability to scavenge, thus require low maintenance yet grow about double the bodyweight of their indigenous counterparts [10], provided that they receive supplementation and are protected against diseases. The two breeds are now being popularized in the country and distributed to farmers by two major poultry multiplication companies in Tanzania.

The multiplication and distribution of these breeds target smallholder farmers thus, they must be tested for performances under various management systems and be recommended accordingly. Therefore, this study intended to test the performance of Kuroiler and Sasso chickens to evaluate their genetic potential under a controlled environment (on-station) and farmer management (on-farm) conditions, and test for genotype $\mathrm{x}$ interactions for economic traits.

\section{MATERIAL AND METHODS}

\section{A. Study Areas and Management of Chicks during Brooding}

This study was conducted on-station and on-farm from December 2018 to December 2019. The on-station study was carried out at Sokoine University of Agriculture while the onfarm experiment was conducted in two villages (i.e., WamiSokoine and Wami-Luhindo) located about $45 \mathrm{~km}$ from the University. The university is located at the foothills of the Uluguru Mountains in Morogoro, Eastern Tanzania, about 550 $\mathrm{m}$ above sea level.

A total of 1200 day-old chicks, 600 for each Kuroiler and Sasso breed were procured from two different commercial companies in the country. Brooding of chicks was done from day-old up to 6 weeks of age at the University poultry farm. Upon arrival, chicks were wing-tagged for identification. Each breed was allocated to 2 brooding pens, each with 300 chicks. During the brooding period, chicks were fed a commercial starter diet in form of crumbles containing $2941 \mathrm{Kcal} \mathrm{ME} / \mathrm{kg}$ and $21.2 \% \mathrm{CP}$ from day old up to the $2^{\text {nd }}$ week of age. A chick mash containing $3049 \mathrm{Kcal} \mathrm{ME} / \mathrm{kg}$ and $20.3 \% \mathrm{CP}$ was then fed from the $3^{\text {rd }}$ up to the $6^{\text {th }}$ week of age. Water was provided $a d$ libitum throughout the brooding period. Birds were also routinely vaccinated against Newcastle, Gumboro, and Fowlpox diseases at specified age intervals. Treatment was provided in case of occurrence of specific disease symptoms. Sexing was done at the end of the brooding period i.e., at weeks 6 of age. The birds of each breed were then divided into two groups, of which 576 (288 Sasso and 288 Kuroiler) were transferred to farmers for on-farm evaluation, and 480 (240 Sasso and 240 Kuroiler) remained at the University poultry farm for on-station evaluation.

B. Management of Birds during Growing and Laying Phases Under On-station and On-farm Management Systems

\section{On-station}

The birds of each breed were randomly allocated to six deep litter pens of 40 birds each and reared under total confinement. They were provided with a commercial grower ration containing $15.5 \% \mathrm{CP}$ and $2762 \mathrm{Kcal} \mathrm{ME} / \mathrm{kg}$, from the $6^{\text {th }}$ to the $19^{\text {th }}$ week of the age. Thereafter, a layer ration containing $18.5 \% \mathrm{CP}$ and $2965 \mathrm{Kcal} \mathrm{ME} / \mathrm{kg}$ was provided from the $20^{\text {th }}$ week of age to the end of the experimental period. Routine vaccinations against Newcastle, as well as anthelmintic, were also given to the birds based on manufacturer instructions. Treatment was provided in case of occurrence of specific disease symptoms.

\section{On-farm}

The selection of villages and households participating in the study was done in collaboration with District and Ward livestock officers. Recruitment of a household (farmer) was based on individual willingness to participate in the research project and his/her ability to provide all necessary management for the chickens including housing, supplementary feeding, health care, etc. In each village 16 farmers (households) were randomly selected from a list of farmers that met the criteria to be included in the study. Out of the 16 farmers in a village, half of them received 18 pre-brooded Sasso and the remaining half received 18 Kuroiler chickens of mixed-sex.

A three days training on proper management of the birds and data recording was provided to participating farmers and two livestock field officers, one for each village. Apart from data recording, the field officers were also responsible for supervising and advising farmers on all management aspects of the birds under field conditions.

Upon arrival in the field, the birds were first weighed individually to obtain the initial body weight. A semi-intensive system of management was adopted whereby a simple enclosure was made around the homestead to restrict other birds from mixing with the experimental birds. The farmers were also responsible for providing housing, supplementary feeding, and basic health care. They were encouraged to make simple formulations to include energy, some protein sources, and minerals in addition to kitchen leftovers.

\section{DATA COLlection}

\section{A. Growth Performance and Feed Conversion Ratio}

The body weight (BW) of chickens was recorded at different ages from the $6^{\text {th }}$ up to $20^{\text {th }}$ weeks of age under both management systems. Birds were weighed individually using a digital weighing scale at the $6^{\text {th }}$ week of age to obtain initial body weight, and then subsequently at $8,12,16$, and 20 weeks of age. Total weight gain (TWG) was calculated as the difference between initial body weight at 6 weeks of age and final body weight at 20 weeks of age. Feed conversion ratio (FCR) was calculated as the amount of feed consumed per unit of body weight gain. This variable was calculated only for birds raised on-station.

\section{B. Egg Production Traits}

Age at first egg was taken as the number of days between hatching date and the date at first egg (i.e., 5\% flock egg production rate). The peak production rate was taken as the maximum weekly \% egg production. Similarly, age at peak egg production was taken as the age of birds at a maximum weekly egg production rate. Hen-housed egg production (HHEP) was 
calculated by dividing the total number of eggs laid in a pen/per household by the number of hens housed at the start of lay. Henday egg production (HDEP\%) was calculated by dividing the number of eggs laid in a pen/per household by the number of hens still alive up to that particular day of recoding [11].

\section{Mortality}

Mortality and its causes were recorded as they occurred during both the growing and the laying periods.

\section{DATA ANALYSIS}

All traits measured were subjected to analysis of variance using the General Linear Models (GLM) procedure of SAS [12] by considering management conditions (i.e., on-station vs onfarm) and breeds as fixed effects, as well as breed $\mathrm{x}$ management interaction effects. Individual farmer or pen effect within a management condition was taken as a random effect. Weight at 6 weeks of age was considered to be a covariate during the analysis of data. Effects of management and breed on survival were tested by a chi-square $\left(\chi^{2}\right)$ test using the frequency procedure [12].

The following statistical model was used to analyze data for body weights (BWT) and total weight gains (TWG) measured on an individual bird basis:

$$
\begin{aligned}
& \mathrm{Y}_{\mathrm{ijkl}}=\mu+\mathrm{M}_{\mathrm{i}}+\mathrm{B}_{\mathrm{j}}+(\mathrm{MB})_{\mathrm{ij}}+\mathrm{FP}(\mathrm{MB})_{\mathrm{ijk}}+\mathrm{b}\left(x_{\mathrm{ijkl}}-\sum \mathrm{x}_{\mathrm{ijkl}} / \mathrm{n}\right) \\
& +\mathrm{E}_{\mathrm{ijk} \mathrm{l}}
\end{aligned}
$$

where

$\mathrm{Y}_{\mathrm{ijkl}}=$ observation (body weight, body weight gain) on the $1^{\text {th }}$ bird from the $\mathrm{k}^{\text {th }}$ farmer or pen within the $\mathrm{j}^{\text {th }}$ breed and $\mathrm{i}^{\text {th }}$ management system;

$\mu=$ General means common to all observations in the study;

$\mathrm{M}_{\mathrm{i}}=$ Effect of the $\mathrm{i}^{\text {th }}$ management system ( $\mathrm{i}=$ on-station, onfarm);

$B_{j}=$ Effect of the $j^{\text {th }}$ breed $(j=$ Kuroiler, Sasso);

$(\mathrm{MB})_{\mathrm{ij}}=$ Effect associated with the interaction between the management system and breed;

$\mathrm{FP}(\mathrm{MB})_{\mathrm{ijk}}=$ Random effect of the $\mathrm{k}^{\text {th }}$ farmer or pen within the $\mathrm{i}^{\text {th }}$ management system and $\mathrm{j}^{\text {th }}$ breed;

$\mathrm{x}_{\mathrm{ijkl}}=$ initial bodyweight of the $\mathrm{l}^{\text {th }}$ bird from the $\mathrm{k}^{\text {th }}$ farmer or pen within the $\mathrm{j}^{\text {th }}$ breed and $\mathrm{i}^{\text {th }}$ management system;

$\sum x_{\mathrm{ijkl}} / n=$ average initial body weight of all birds in the study;

$\mathrm{b}=$ Regression of body weight /body weight gain on initial body weight;

$\mathrm{E}_{\mathrm{ijk} \mathrm{k}}=$ Random effects peculiar to each bird.

For egg production and other traits observed on pen or household basis (i.e., the pen or household was the observation unit) were analyzed by using the following statistical model:

$$
\mathrm{Y}_{\mathrm{ijkl}}=\mu+\mathrm{M}_{\mathrm{i}}+\mathrm{B}_{\mathrm{j}}+(\mathrm{MB})_{\mathrm{ij}}+\mathrm{FP}(\mathrm{MB})_{\mathrm{ijk}}+\mathrm{E}_{\mathrm{ijkl}}
$$

where:

$\mathrm{Y}_{\mathrm{ijk}}=$ observation (Egg production variables) from the $\mathrm{k}^{\text {th }}$ farmer or pen within the $\mathrm{j}^{\text {th }}$ breed and $\mathrm{i}^{\text {th }}$ management system; $\mu=$ General mean common to all observations in the study;

$\mathrm{M}_{\mathrm{i}}=$ Effect of the $\mathrm{i}^{\text {th }}$ management system ( $\mathrm{i}=$ on-station, onfarm);

$\mathrm{B}_{\mathrm{j}}=$ Effect of the $\mathrm{j}^{\text {th }}$ breed $(\mathrm{j}=$ Kuroiler, Sasso);
$(\mathrm{MB})_{\mathrm{ij}}=$ Effect associated with the interaction between the management system and breed;

FP(MB)ijk= Random effect of the $\mathrm{k}^{\text {th }}$ farmer or pen within the $\mathrm{i}^{\text {th }}$ management system and $\mathrm{j}^{\text {th }}$ breed;

$\mathrm{E}_{\mathrm{ijkl}}=$ Random effects peculiar to each bird.

Note: The effects of the management system and breed for body weight and egg production variables were tested using the farmer or pen variation within the management system and breed (i.e., FP(MB)ijk) as the error term.

For feed conversion ratio, Model 1 was modified to model 3 where the effects of the management system and interaction between the management system and breed were removed because FCR was measured under on-station experiment only.

$$
Y_{i j k}=\mu+B_{i}+b\left(x-\sum x / n\right)_{i j}+E_{i j k}
$$

All descriptions are similar to model 1 except:

$$
\mathrm{Y}_{\mathrm{ijk}}=\text { observation }(\text { Feed conversion ratio) }
$$

\section{Results}

A. Effects of Management and Breed on Growth Performance of Kuroiler and Sasso Chickens

The least-square means for body weight (BW), total weight gain (TWG), and average daily gain (ADG) of chickens summarized by management system and breed are presented in Table I. The overall results during the growing phase show that the management system significantly $(\mathrm{P}<0.05)$ influenced the body weight and weight gain of the two breeds. Chickens reared under on-station management were heavier and gained more weight than the chickens reared under on-farm management. Breed effects were insignificant $(\mathrm{P}>0.05)$ for body weight and body weight gain. The results further show that FCR differed significantly $(\mathrm{P}<0.05)$ between the two breeds whereby, Sasso had a lower feed conversion ratio compared to Kuroiler. Significant interaction effects $(\mathrm{P}<0.05)$ between the management system and breed were observed on BW, TWG, and ADG (Table II).

\section{B. Effects of Management System and Breed on Egg Production of Kuroiler and Sasso Chickens}

The least-square means for egg production traits summarized by management systems and breeds are presented in Table III. The results show that there were significant differences $(\mathrm{P}<0.05)$ between management systems on all egg production traits studied in favor of the on-station management system. The general effects of the breed were significant $(\mathrm{P}<0.05)$ only for HDEP and HHEP where Sasso outperformed Kuroiler. No significant differences $(\mathrm{P}>0.05)$ were observed between the two breeds for age at first egg, peak egg production rate, and age at peak egg production. Significant interaction effects $(\mathrm{P}<0.05)$ between the management system and breed were observed for all egg production traits except for peak egg production rate which was not significant (Table IV). 
TABLE I: LSM \pm SEM VALUES FOR GROWTH PERFORMANCE TRAITS OF CHICKENS SUMMARIZED BY MANAGEMENT SYSTEMS AND BREEDS

\begin{tabular}{ccccc}
\hline \multirow{2}{*}{ Fixed effects } & \multicolumn{5}{c}{ Variables } \\
\cline { 2 - 5 } & BW at week 6 $(\mathrm{g})$ & BW at week 20 $(\mathrm{g})$ & Total weight gain $(\mathrm{g})$ & Average daily gain $(\mathrm{g})$ \\
\hline Management system & & & & \\
On-station & $541.4 \pm 3.3$ & $2510.9 \pm 16.4^{\mathrm{a}}$ & $1977.3 \pm 16.4^{\mathrm{a}}$ & $20.2 \pm 0.2^{\mathrm{a}}$ \\
On-farm & $536.0 \pm 3.0$ & $1870.5 \pm 16.1^{\mathrm{b}}$ & $1336.9 \pm 16.1^{\mathrm{b}}$ & $13.6 \pm 0.2^{\mathrm{b}}$ \\
Breed & & & & \\
Kuroiler & $527.0 \pm 3.2^{\mathrm{b}}$ & $2154.1 \pm 15.8$ & $1620.5 \pm 15.9$ & $16.5 \pm 0.2$ \\
Sasso & $550.4 \pm 3.2^{\mathrm{a}}$ & $2227.3 \pm 16.9$ & $1693.7 \pm 16.9$ & $17.3 \pm 0.2$ \\
\hline
\end{tabular}

${ }^{\text {a-b }}$ Means with different superscripts within a column and effect are significantly different $(\mathrm{P}<0.05)$, LSM = least-squares mean, SEM = Standard error of the mean, $\mathrm{BW}=$ Bodyweight.

TABLE II: LSM \pm SEM VALUES FOR THE INTERACTION EFFECTS OF MANAGEMENT SYSTEMS AND BREEDS ON GROWTH PERFORMANCE TRAITS OF CHICKENS

\begin{tabular}{ccccccc}
\hline \multicolumn{2}{c}{ Fixed effects } & \multicolumn{5}{c}{ Variables } \\
\hline $\begin{array}{c}\text { Management } \\
\text { system }\end{array}$ & Breed & BW at week 6 $(\mathrm{g})$ & BW at week 20 $(\mathrm{g})$ & $\begin{array}{c}\text { Total Weight } \\
\text { Gain }(\mathrm{g})\end{array}$ & $\begin{array}{c}\text { Average Daily } \\
\text { Gain }(\mathrm{g})\end{array}$ & FCR \\
\hline On-station & Kuroiler & $529.3 \pm 4.7^{\mathrm{b}}$ & $2313.1 \pm 22.7^{\mathrm{b}}$ & $1779.4 \pm 22.7^{\mathrm{b}}$ & $18.2 \pm 0.2^{\mathrm{b}}$ & $5.8 \pm 0.1^{\mathrm{a}}$ \\
& Sasso & $553.5 \pm 4.7^{\mathrm{a}}$ & $2708.8 \pm 23.8^{\mathrm{a}}$ & $2175.2 \pm 23.8^{\mathrm{a}}$ & $22.2 \pm 0.2^{\mathrm{a}}$ & $4.8 \pm 0.1^{\mathrm{b}}$ \\
& & & & & & - \\
On-farm & Kuroiler & $524.6 \pm 4.3^{\mathrm{b}}$ & $1995.2 \pm 22.1^{\mathrm{c}}$ & $1461.6 \pm 22.1^{\mathrm{c}}$ & $14.9 \pm 0.2^{\mathrm{c}}$ & - \\
& Sasso & $547.3 \pm 4.3^{\mathrm{a}}$ & $1745.9 \pm 23.7^{\mathrm{d}}$ & $1212.3 \pm 23.7^{\mathrm{d}}$ & $12.4 \pm 0.2^{\mathrm{c}}$ & - \\
\hline
\end{tabular}

${ }^{\mathrm{a}-\mathrm{d}}$ Means with different superscripts between breeds within management system are significantly different $(\mathrm{P}<0.05), \mathrm{LSM}=$ least-squares mean, SEM $=$ Standard error of the mean, $\mathrm{BW}=$ Bodyweight, $\mathrm{FCR}=$ Feed conversion ratio.

TABLE III: LSM \pm SEM VALUES FOR EGG PRODUCTION TRAITS OF CHICKENS SUMMARIZED By MANAGEMENT Systems AND BREEDS

\begin{tabular}{cccccc}
\hline Fixed effects & \multicolumn{5}{c}{ Variables } \\
\cline { 2 - 5 } & $\begin{array}{c}\text { Age at first egg } \\
\text { (days) }\end{array}$ & $\begin{array}{c}\text { Hen-housed egg } \\
\text { production (\%) }\end{array}$ & $\begin{array}{c}\text { Peak egg production } \\
\text { rate (\%) }\end{array}$ & $\begin{array}{c}\text { Age at peak } \\
\text { production (week) }\end{array}$ & $\begin{array}{c}\text { Hen-day egg } \\
\text { production (count) }\end{array}$ \\
\hline Management & & & & & \\
On-station & $153.4 \pm 1.7^{\mathrm{b}}$ & $56.4 \pm 2.6^{\mathrm{a}}$ & $81.1 \pm 3.3^{\mathrm{a}}$ & $34.5 \pm 0.2^{\mathrm{b}}$ & $108.3^{\mathrm{b}} \pm 4.3^{\mathrm{a}}$ \\
$\quad \begin{array}{c}\text { On-farm } \\
\text { Breed }\end{array}$ & $179.1 \pm 1.2^{\mathrm{a}}$ & $34.9 \pm 0.7^{\mathrm{b}}$ & $66.0 \pm 2.6^{\mathrm{b}}$ & $37.3 \pm 0.3^{\mathrm{a}}$ & $50.5 \pm 1.2^{\mathrm{b}}$ \\
Kuroiler & $166.5 \pm 1.5$ & $41.9 \pm 2.5^{\mathrm{b}}$ & $74.7 \pm 3.0$ & $36.2 \pm 0.3$ & $71.3 \pm 4.1^{\mathrm{b}}$ \\
Sasso & $166.1 \pm 1.5$ & $49.5 \pm 1.1^{\mathrm{a}}$ & $72.3 \pm 3.0$ & $35.6 \pm 0.3$ & $87.5 \pm 1.8^{\mathrm{a}}$ \\
\hline
\end{tabular}

${ }^{\mathrm{a}-\mathrm{b}}$ Means with different superscripts within a column and effect are significantly different $(\mathrm{P}<0.05), \mathrm{LSM}=$ least-squares mean, $\mathrm{SEM}=\mathrm{Standard}$ error of the mean.

TABLE IV: LSM \pm SEM VALUES FOR THE INTERACTION EFFECTS OF MANAGEMENT SySTEMS AND BREEDS ON EGG PRODUCTION TRAITS OF CHICKENS

\begin{tabular}{ccccccc}
\hline \multicolumn{2}{c}{ Fixed effects } & \multicolumn{5}{c}{ Variables } \\
\hline $\begin{array}{c}\text { Management } \\
\text { system }\end{array}$ & Breed & $\begin{array}{c}\text { Age at first egg } \\
\text { (days) }\end{array}$ & $\begin{array}{c}\text { Hen-housed egg } \\
\text { production }(\%)\end{array}$ & $\begin{array}{c}\text { Peak egg } \\
\text { production rate } \\
(\%)\end{array}$ & $\begin{array}{c}\text { Age at peak } \\
\text { production } \\
\text { (week) }\end{array}$ & $\begin{array}{c}\text { Hen-day egg } \\
\text { production } \\
\text { (count) }\end{array}$ \\
\hline On-station & Kuroiler & $159.2 \pm 2.5^{\mathrm{c}}$ & $49.1 \pm 4.9^{\mathrm{b}}$ & $83.2 \pm 4.7^{\mathrm{a}}$ & $35.3 \pm 0.3^{\mathrm{b}}$ & $91.4 \pm 8.0^{\mathrm{b}}$ \\
& Sasso & $147.7 \pm 2.5^{\mathrm{d}}$ & $63.7 \pm 1.9^{\mathrm{a}}$ & $78.9 \pm 4.7^{\mathrm{a}}$ & $33.7 \pm 0.3^{\mathrm{c}}$ & $125.2 \pm 3.1^{\mathrm{a}}$ \\
\multirow{2}{*}{ On-farm } & Kuroiler & $173.8 \pm 1.7^{\mathrm{b}}$ & $34.5 \pm 1.0^{\mathrm{c}}$ & $66.2 \pm 3.6^{\mathrm{b}}$ & $37.0 \pm 0.4^{\mathrm{a}}$ & $51.3 \pm 1.6^{\mathrm{c}}$ \\
& Sasso & $184.5 \pm 1.7^{\mathrm{a}}$ & $35.2 \pm 1.0^{\mathrm{c}}$ & $65.7 \pm 3.7^{\mathrm{b}}$ & $37.5 \pm 0.4^{\mathrm{a}}$ & $49.8 \pm 1.7^{\mathrm{c}}$ \\
\hline
\end{tabular}

${ }^{\mathrm{a}-\mathrm{d}}$ Means with different superscripts between breeds within management system are significantly different $(\mathrm{P}<0.05), \mathrm{LSM}=$ least-squares mean, $\mathrm{SEM}=\mathrm{Standard}$ error of the mean.

TABLE V: Mortality RATES OF BIRds (\%) DURING THE GROWING AND LAYING PHASES SuMMARIZED By MANAGEMENT SySTEMS, BREEDS, AND BREEDS WITHIN A MANAGEMENT SYSTEM

\begin{tabular}{|c|c|c|c|c|c|c|c|}
\hline \multirow{3}{*}{ Fixed effects } & & \multirow{2}{*}{\multicolumn{3}{|c|}{ Growing phase }} & \multirow{2}{*}{\multicolumn{3}{|c|}{ Laying phase }} \\
\hline & & & & & & & \\
\hline & & Mortality & $x^{2}$-test & P-value & Mortality & $x^{2}$-test & P-value \\
\hline \multirow[t]{2}{*}{ Management } & On-station & 10.6 & 24.3792 & $* * *$ & 17.0 & 53.7141 & $* * *$ \\
\hline & On-farm & 22.1 & & & 47.1 & & \\
\hline \multirow[t]{2}{*}{ Breed } & Kuroiler & 12.5 & 14.2977 & $* * *$ & 30.9 & 1.5680 & ns \\
\hline & Sasso & 21.2 & & & 36.1 & & \\
\hline \multirow[t]{2}{*}{ On-station } & Kuroiler & 7.5 & 4.9362 & $*$ & 16.5 & 0.0402 & ns \\
\hline & Sasso & 13.7 & & & 17.5 & & \\
\hline \multirow[t]{2}{*}{ On-farm } & Kuroiler & 16.7 & 9.7072 & $* *$ & 43.1 & 1.8581 & ns \\
\hline & Sasso & 27.4 & & & 51.0 & & \\
\hline
\end{tabular}

C. Effect of Management System and Breed on the Survivability of Kuroiler and Sasso Chickens

The mortality rates of the birds during the growing and laying phases are summarized by management systems, breeds, and breeds within management systems (Table V). There were significant differences $(\mathrm{P}<0.05)$ between the two management systems for the survivability of chickens. Birds reared under on-station management had lower mortality rates (growing
$10.6 \%$ and laying $17.0 \%$ ) than birds reared under on-farm management (growing $22.1 \%$ and laying $47.1 \%$ ). The general effect of the breed was significant $(\mathrm{P}<0.05)$ only during the growing period where Sasso had a higher percentage of deaths $(21.2 \%)$ than Kuroiler $(12.5 \%)$. Breed effects within the management system were significant only during the growing period, where Kuroiler had lower mortality rates than Sasso under both management systems i.e. (on-station $7.5 \%$ vs. onfarm $16.7 \%$ ) and (on-station $13.7 \%$ vs. on-farm $27.4 \%$ ) for 
Kuroiler and Sasso respectively. No significant difference $(\mathrm{P}>0.05)$ was observed for mortality rates of the two breeds within the management system during the laying period. In general, a higher percentage of mortality of chickens had occurred during the laying than during the growing period, where the on-farm management system encountered more deaths.

\section{DISCUSSION}

Performance traits are mostly affected by genotype (breed, strain, lines, ecotype, etc.) and environment (management system, nutrition, diseases, etc.). In this study, most of the traits studied were affected by both genotype and environment depending on the stage of growth. The mean body weight and body weight gain of chickens reared on-station were higher than of those chickens reared on-farm, implying a higher growth rate under on-station than on-farm conditions. The most likely explanation for the higher growth performance of onstation birds could be the provision of formulated rations throughout the experimental period. The on-farm birds were only supplemented with any available feeds at the household mainly maize bran and kitchen leftovers, which may not supply the sufficient nutrients required for growth. This suggests that the on-farm management conditions were less favorable for the two breeds unless higher levels of supplementation are adopted. This observation is supported by the results reported previously [13]-[15]. Besides, Bekele et al [16] and Kayitesi [17] argued that chickens reared under semi-scavenging spend most of their time searching for feed. This results in much loss of energy that could otherwise be used for production including weight gain and egg production.

In general, the two breeds did not differ significantly in respect of body weight and body weight gain. However, important interactions were observed between breeds and management systems on these variables. It was found that, whereas Sasso birds reared under an on-station management system were heavier and grew faster than Kuroiler birds, they performed poorer than Kuroiler birds under an on-farm management system. The higher growth performance of Sasso than Kuroiler chickens under on-station management conditions could be explained by its lower feed conversion ratio. This may suggest that the breed is more efficient at converting feed to live bodyweight. A similar observation has been also reported by Sanka et al [18] when comparing Kuroiler and Sasso chickens fed different diets. On the other hand, the lower performance of Sasso than Kuroiler chickens under onfarm management conditions has also been reported by Kidie [19] under similar management systems in Ethiopia. This probably suggests that the Sasso breed needs relatively better management conditions to express its full genetic potential. It is also likely that the Sasso breed has less scavenging ability than that of Kuroiler, hence failed to efficiently utilize the available scavenging feed resources under the on-farm conditions.

The bodyweight of Sasso chickens observed in the present study at 20 weeks of age under on-station management is within the range of 2343.7 to $2962.1 \mathrm{~g}$ reported by Bamidele et al [20] for the similar breed, age, and management system in Nigeria. Similarly, the observed body weight of Kuroiler chickens at 20 weeks of age in the present study falls within the range of
$1728 \pm 8.2$ to $1909 \pm 4.0 \mathrm{~g}$ reported by Kidie [19]. However, Assefa et al [21] reported that the mean body weight of Sasso chickens ranged from 3.01 to $3.23 \mathrm{~kg}$ under on-farm management conditions, which was much higher than what was observed in the present study. The genetic differences between lines, variation in supplementary feeds, and availability of scavengable feed resources in the respective areas could explain the observed difference between the current result and those reported by Assefa et al [21].

The on-station management system also outperformed the on-farm management system in all egg production characters, as was the case for body weight and other characters. Birds under the on-station management system laid their first egg about 25 days earlier and reached peak production earlier than those under the on-farm management system. It was further observed that the hen-housed egg production (HHEP) under onstation management was twice as much that of the on-farm management birds. Also, the on-farm birds had $21.5 \%$ and $15.1 \%$ lower hen-day egg production and peak egg production respectively, than the on-station birds. Studies elsewhere in the tropics have also reported better performance of on-station birds over those under on-farm management [22], [16]. The lower performance of on-farm birds might have been due to the prevalence of diseases and infrequent feed supplementation to birds which in most cases depended on seasons and household practices. A similar notion has been expressed by Goromela et al [23] and Knueppel et al [24].

The observed significant interactions between the management system and breed on hen-housed egg production, hen day egg production, and age at peak egg production rate in the present study imply that the two breeds differed in their response to management systems. It was observed that while the two breeds performed similarly in respect of hen-day egg production, age at peak production, and hen-housed egg production under the on-farm management system, Sasso chickens outperformed Kuroiler for these characters under the on-station management system. This observation may imply that the Sasso breed needs relatively better management than the Kuroiler for them to express its full genetic potential. Nevertheless, this observation is contradictory to that of Bamidele et al [20] who observed that Kuroiler chickens outperformed Sasso chickens in HHEP under on-station management. Such contradiction is not surprising since this character depends also on factors such as temperature, disease, and the ability of the birds to tolerate these effects. For example, [25] and [16] reported contradictory results on HHEP where Rhode Island Red breed (RIR) was superior to Fayoumi in an earlier study whereas the reverse was observed in a latter study. This was attributed to the slow recovery of RIR against Fowlpox disease. On the other hand, the HHEP for Kuroiler and Sasso chickens observed in the present study under on-farm management are lower than $77.60 \pm 1.74$ eggs of the Vanaraja dual-purpose breed reported by Singh et al [26] under backyard management in India.

The age at first egg is deemed to be the age of attainment of sexual maturity of the chickens and is an important economic egg production character. In this study, Sasso chickens matured earlier than Kuroilers under the on-station management system, while the reverse was observed under the on-farm management system. The Sasso also attained a peak egg production rate earlier than the Kuroiler under the on-station management 
system. The better performance of Sasso than Kuroiler in respect of age at sexual maturity and age at peak egg production under on-station conditions might be attributed to its higher live body weight at the onset of egg production. According to Olawumi [27], body weight is among the factors that determine the age at first egg, age at egg peak production, and overall performance. It is to be noted that the Sasso breed was also heavier than the Kuroiler under on-station management as has been explained earlier. A similar observation was reported by [27] for Bovan Nera chickens when they were compared with other genotypes under an on-station management system in Nigeria. In comparison to the present findings on age at first egg under on-farm management conditions, [28], [19], [29] reported lower age at the first egg for Sasso i.e., 157.2, 176, and 177 days respectively. Likewise, Bamidele et al [20] reported the age at first egg of $120 \pm 1.3$ and $133 \pm 0.6$ days for Kuroiler and Sasso, respectively under on-station management, values which were also lower than those of the present study. However, Islam et al [30] and Kidie [19] reported the mean age at first egg of 184 days for Kuroiler under an on-farm management system, which was higher than that of the present study for the similar breed and management conditions. Differences in nutritional level, availability of scavengable feed resources, and other environmental factors might be the reasons for the differences between the results obtained in the present study and those from other authors.

Concerning survivability of chickens, higher mortality rates were observed for the birds raised under the on-farm than under the on-station management conditions. The high mortality rates under on-farm management were mainly due to diseases and other unknown reasons. Probably poor management practices including inadequate feeding, poor housing, and health care might be the predisposing factors for mortality. This observation is similar to the report of several authors [15], [13], [17], [31]. The on-station mortality rates in the present study were mainly due to diseases and cannibalism (cloaca pecking) during the growing and laying periods, respectively. It has been suggested that the exposure of the cloacal mucous membranes soon after the actual expulsion of an egg may attract other hens which start vent pecking [32]. This probably attracted the chickens to develop such behavior, although the actual cause of cannibalism was not considered for analysis. The on-station mortality rates observed in this study are within the range of 5.5 to $13.0 \%$ and 16.0 to $28.3 \%$ during the growing and laying periods, respectively reported by Bamidele et al [20] for similar breeds and similar management conditions in Nigeria.

The present study also revealed that a higher percentage of mortality occurred during the laying than during the growing period. This could partially be explained by the fact that the laying period in this study coincided with the dry season, which is associated with insufficient feed sources and the occurrence of several diseases affecting chickens in rural areas [33], [34]. This observation agrees with the argument put forward by Kidie [19] that inadequate feeding and imbalanced nutrition, especially at the peak of production, may lead to high percentages of mortality as at that period birds require balanced rations for body maintenance and egg production. Higher mortality rates during the laying period than during the growing period were also reported by Bekele et al [16] in Ethiopia. Generally, Kuroiler had a comparatively higher survival rate than the Sasso under both management systems. Bamidele et al
[20] reported similar observations under on-station management conditions in Nigeria. The genetic differences and the ability of the breed to tolerate environmental stress in a particular environment might have been the reasons for such variation. Kuroiler chickens are said to be resistant to infectious diseases as reported from other studies [7], [35], [36]. This observation is also supported by the findings from the study by Mpenda et al [37] who reported higher antibody titers in Kuroiler chickens than in other breeds.

\section{CONCLUSION}

Based on the results of the present study, it is concluded that there is a large difference between the on-station and the onfarm management systems for all chicken performance traits studied. Also, a bird's performance depends on the interaction between the breed and the management system. The Kuroiler seemly to cope comparatively better than Sasso under suboptimal management conditions while the Sasso excelled under improved management. Thus, the introduction of improved chicken genotypes to farmers should go hand in hand with the provision of knowledge on the overall management of the birds for improved productivity. However, cost-benefit studies are recommended for these introduced breeds to understand their economic viability under the on-station and on-farm management conditions.

\section{ACKNOWLEDGMENT}

This research was carried out under the financial support of the African Chicken Genetic Gains (ACGG) project in Tanzania sponsored by the Bill and Melinda Gates Foundation (Grant Agreement OPP1112198). The authors express their appreciation to the Department of Animal, Aquaculture, and Range Sciences of Sokoine University of Agriculture for providing necessary facilities for on-station study. We are further grateful to households and field officers who participated in the project for their cooperation during data collection under the on-farm study.

\section{ETHICAL STATEMENT}

Conflict of interest: The authors declare that they have no conflict of interest.

Statement of animal rights: National and institutional procedures for the care and use of animals were followed. The study was approved by the International Livestock Research Institute Institutional Animal Care and Use Committee (ILRI IACUC) with reference number: IACUC-RC2016.26.

\section{REFERENCES}

[1] Aklilu, H., Almekinders, C.J.M., Udo, H.M.J and Van der Zijpp, A.J. (2007). Village poultry consumption and marketing in relation to gender, religious festivals and market access. Tropical Animal Health and Production 39, 165-168.

[2] MLFD (2015). Ministry of Livestock and Fisheries Development. Tanzania livestock modernization initiative. Dar es Salaam, Tanzania: Ministry of Livestock and Fisheries Development. Available: https://livestocklivelihoodsandhealth.org/wpcontent/uploads /2015/07/Tanzania_Livestock_Modernization_Initiative_July_2015.pdf. 
[3] Permin, A. (2008). Good practices in small-scale poultry production: A manual for trainers and producers in East Africa. A Consultancy Report to FAO, FAO ECTAD Regional Unit Eastern Africa, Nairobi, Addis Ababa, Ethiopia.

[4] Ali, K.O., Katule, A.M. and Syrstad, O. (2000). Genotype X Environment interaction for growing chickens: Comparison of four genetic groups on two rearing systems under tropical condition, Acta Agriculturae Scandinavica, Section A-Animal Sciences, 50(2), 65-71.

[5] Da Silva, M., Desta, S. and Stapleton, J. (2017) Development of the chicken sector in the Tanzanian Livestock Master Plan. Available: https://core.ac.uk/download/pdf/132697821.pdf.

[6] Sharma, J., Xie, J., Boggess, M., Galukande, E., Semambo, D. and Sharma S. (2015). Higher weight gain by Kuroiler chickens than indigenous chickens raised under scavenging conditions by rural households in Uganda. Livestock Research for Rural Development, 27(9).

[7] SASSO (2014). Coloured chicken genetics. Available: http://www.sasso.fr/coloured-chicken-genetics-for-organic-red-labelfarmer-chickens.html.

[8] Ahuja, V., Dhawan, M., Punjabi, M. and Maarse, L. (2008). Poultrybased livelihoods of rural poor: Cast of Kuroiler in West Bengal. Research report document 012. South Asia Pro-Poor Livestock Policy Programme. Available: http: //www. drcsc.org/VET/ library/Animal/BkPoultry_Based_Livelihoods.pdf.

[9] Mengsite, F.W., Yitbarek, M.B. and Getachew, E. (2019). Productivity and Egg Quality Traits of Sasso T44 Chicken in North Showa Zone, Ethiopia. Journal of Animal and Plant Sciences 39 (3), 6478-6486.

[10] Sharma, J. (2011). A new breed: Highly productive chickens help raise Ugandans from poverty researcher at the Center for Infectious Diseases and Vaccinology at ASU's Bio-design Institute. Available: https://asunews.asu.edu/ node/21034.

[11] North, M.O. (1984). Breeder Management. In Commercial Chicken Production Manual. The Avi. Publishing Company. Inc. Westport, Connecticut. 240-243, 298-321 pp.

[12] SAS (2009). Statistical Analytical System. User Guide for Personal Computers, Statistical Programme. Windows Version 9.2, SAS Institute Inc. Cary, NC, USA.

[13] Lwelamira, J., Kifaro, G.C. and Gwakisa, P.S. (2008). On station and onfarm evaluation of two Tanzania chicken ecotypes for body weights at different ages and for egg production. African Journal of Agricultural Research, 3(12), 843-851.

[14] Magala, H., Kugonza, D.R., Kwizera, H. and Kyarisiima, C.C. (2012). Influence of management system on growth and carcass characteristics of Ugandan local chickens. Journal of Animal Science Advances 2(6), 558567.

[15] Wondmeneh, E., Van der Waaij, E.H., Udo, H.M.J., Tadelle, D. and Van Arendonk, J.A.M. (2016). Comparison of different poultry breeds under station and on-farm conditions in Ethiopia. Livestock Science 183 (2016) 72-77. Available: http://dx.doi.org/10.1016/j.livsci.2015.11.019.

[16] Bekele, F., Gjøen, H.M., Kathle, J., Ådnøy, T. and Abebe, G. (2009). Genotype X environment interaction in two breeds of chickens kept under two management systems in Southern Ethiopia. Tropical Animal Health and Production 41:1101-1114. Available: https://www.researchgate.net/publication/23665839.

[17] Kayitesi, A. (2015). Management systems and location effects on growth and carcass traits of Kuroiler and Local chickens. MSc Thesis. Makerere University, Uganda.

[18] Sanka, Y.D., Mbaga, S.H., Mutayoba, S.K., Katule, A.M. and Goromela, S.H. (2020). Evaluation of growth performance of Sasso and Kuroiler chickens fed three diets at varying levels of supplementation under semiintensive system of production in Tanzania. Tropical Animal Health and Production 52(6), 3315-3322

[19] Kidie, H.A. (2019). Characterization of chicken production system and on-farm evaluation of introduced exotic chicken breeds in Gondar Zuria and Kalu districts of Amhara region, Ethiopia. MSc Thesis. Haramaya University, Haramaya, Ethiopia.

[20] Bamidele, O., Sonaiya, E.B., Adebambo, O.A. and Dessie, T. (2019). Onstation performance evaluation of improved tropically adapted chicken breeds for smallholder poultry production systems in Nigeria. Tropical Animal Health and Production. Available: https://doi.org/10.1007/s11250-019-02158-9.

[21] Assefa, S., Melesse, A. and Banerjee, S. (2018). Egg production and linear body measurement traits of local and three exotic chicken genotypes reared under two agroecological zones. International Journal of Ecology and Ecosolution 5(2), 18-23.

[22] Sazzad, M.H. (1992). Comparative study on egg production and feed efficiency of different breeds of poultry under intensive and rural conditions in Bangladesh. Livestock Research for Rural Development 4(3): 65-69. Available:

http://www.fao.org/ag/aga/agap/frg/lrrd/lrrd4/3/bangla1.htm.
[23] Goromela, E. H., Kwakkel, R. P., Verstegen, M. W. A. and Katule, A. (2006). Strategies to optimize the use of scavengeable feed resource base by smallholder poultry farmers. African Journal of Agricultural Research 1: 91-100. Available: http://www.academicjournals.org/AJAR.

[24] Knueppel, D., Peter, C., Ayubu, O.M., Peter, M., David, M. and Carol, C. (2009). Improving Poultry Production for Sustainability in the Ruaha Landscape, Tanzania. Wildlife Conservation Society, 24.

[25] Akhtar, N., Mahmood, S., Hassan, M. and Yasmeen, F. (2007). Comparative study of production potential and egg characteristics of Lyallpur Silver Black, Fayoumi and Rhode Island Red breeds of poultry, Pakistan Veterinary Journal, 27(4), 184-188.

[26] Singh, P., Kachroo, D., Thakur, N.P., Khajuria, V., Kumar, P., Kumar, M., and Kour, G. (2018). Comparative Performance of Vanaraja, Gramapriya, and Indigenous Desi Bird under Backyard System of Rearing in Jammu Province, India. International Journal of Current Microbiology and Applied Sciences 7(02), 101-105. Available: https://doi.org/10.20546/ijcmas.2018.702.013.

[27] Olawumi, S.O. (2011). Study on pre-laying characteristics of three breeds of commercial layers in the Derived Savannah Zone of Nigeria. Pakistan Journal of Biological Sciences 14(23), 1061-1065.

[28] Kejela, Y. (2020). Production Performance of Chicken under Farmers' Management and Their Roles at Urban Household Economy in Southern Ethiopia. Agricultural Sciences 11: 178-190.

[29] Getiso, A., Jimma, A., Asrat, M., Kebede, H.G., Zeleke, B. and Birhanu, T. (2017). Management practices and productive performances of Sasso chickens breed under village production system in SNNPR, Ethiopia. Journal of Biology, Agriculture and Healthcare 7 (7): 120-135.

[30] Islam, R., Deka, C.K., Rahman, M., Deka, B.C., Hussain, M. and Paul, A. (2017). Comparative performances of Kuroiler, Rainbow Rooster and Indigenous birds under backyard system of rearing in Dhubri district of Assam. Journal of Rural and Agricultural Research 17 (1), 40 - 43.

[31] Abalaka G.O., Mkpado M. and Ugwu S.O.C. (2013). Rearing methods, seasons of the year, and survivability of rural poultry enterprise in Nigeria. Journal of Agriculture and Sustainability, 3(1), 27-55.

[32] Savory, C.J. (1995) Feather pecking and cannibalism. World's Poultry Science Journal, 51: 215-219.

[33] Mwalusanya, N.A., Katule, A.M., Mutayoba, S.K. and Mtambo, M.M.A. (2002). Productivity of local chickens under village management conditions. Tropical Animal Health and Production 34: 405-416.

[34] Alem T (2014). Production and reproduction performance of rural poultry in lowland and midland agro-ecological zones of Central Tigray, Northern Ethiopia. African Journal of Agricultural Research 9(49):35313539.

[35] Fleming, D.S., Koltes, J. E., Markey, A.D., Schmidt, C.J., Ashwell, C.M., Rothschild, M.F., Persia, M.E., Reecy, J.M. and Lamont, S.J. (2016). Genomic analysis of Ugandan and Rwandan chicken ecotypes using a 600 k genotyping array. BMC Genomics 17: 407.

[36] Okumu, N.O. (2016). Genetic diversity and viral disease resistance of the indigenous chickens from selected areas in Kenya. MSc Thesis, Kenyatta University, Kenya.

[37] Mpenda, F.N., Lyantagaye, S.L. and Buza, J. (2020). Immune response following Newcastle disease immunization and growth performance of Kuroiler, broiler, and local Tanzanian chickens. International Journal of Livestock Production, 11(1), 1-7. 